\title{
The Degree of Faculty Practice for Emotional Intelligence from
}

\section{Their Points of Views}

\author{
Dr. Sulaiman Hajaia ${ }^{{ }^{*}}$ \\ ${ }^{1}$ Department of Educational Psychology, Faculty of Educational Sciences, Tafila Technical University, \\ Tafila, Jordan \\ *Dr. Sulaiman Hajaia, E-mail: sulimanhajaia@yahoo.com
}

Received: July 8, 2017

Accepted: July 18, 2017

Online Published: July 27, 2017

doi:10.22158/wjer.v4n3p405

URL: http://dx.doi.org/10.22158/wjer.v4n3p405

\begin{abstract}
The study aimed at investigating the degree of faculty practice for emotional intelligence from their point of views. The sample of the study consisted of 153 faculties from Tafila Technical University (TTU). The researcher developed an emotional intelligence practices scale. The results indicated that the faculty practices of emotional intelligence were mid. There were statistically significant differences in practicing emotional intelligence attributed to college in favor of: humanity colleges, faculty with more than 7 year experience, and faculty whose their academic rank were associate prof. and prof. The result also indicated that the interaction between academic rank and experience was statistically significant in favor of associate prof and prof with less than 7 year experience.
\end{abstract}

\section{Keywords}

Emotional Intelligence, faculty, university

\section{Introduction and Literature Review}

Emotional Intelligence (EI) is considered to be the last type of intelligences that appeared in the field of educational psychology. It plays a great role in human life because it enables us to adapt with life situations and provides different methods to solve our problems (Alwan, 2011). The history of EI refers to the works of Mayer and salvoey (1990), when they examined the individual differences in EI and they found that individuals differ in their EI abilities and the way they express their emotions and react to the others emotions. The emotionally intelligent people have the ability to monitor his and the others feelings; and this enables him to control his behavior (Johnson, 2008; George, 2000). The study of EI raised from: individuals differ in their emotional skills according to the individual differences, and this type of intelligence was not included in the intelligence measures. EI is correlated with many variables such as, personality, mode, social skills, and adaptation to life (Rfou, 2011). Alamarat (2014) indicated that $\mathrm{EI}$ is a dominated force that controls human negative and positive abilities. 
EI became an important issue in industrial, administrative, educational and military establishments because social and emotional abilities form the basics of the individuals thinking and cognitive skills which will be converted and translated into work power, productivity and success (Rfou, 2011; Alharahsha, 2013). The availability of EI in the academic leader makes him able to realize the organization climate to perform the job tasks efficiently, and establishes good social relations with students. According to that, the students become more motivated, and achieve the learning goals (Allawzi, 2012). Goleman (1995) introduced EI model which consists of 5 dimensions: self awareness of emotions, self regulation of emotions, self organization of emotions, motivation, and sympathy and social skills. Livenson (1999) suggested another model for EI: emotional awareness, feeling control, trust and consciousness, integration and responsibility, and sensitivity to the others need. Bur-on (2006) divided EI into the following 5 dimensions: personal, social, adaptation, stress management and general mode.

The scales were used to measure EI which were varied according to the definition of EI concept; is it a personal trait? Or mental ability? Or individual competency. For this study purposes the following dimensions were adopted to measure EI:

- Emotional management: the ability to control self-emotion in different social situations, and the ability to control and affect others emotions.

- Social communication: the ability to communicate with others emotions through successive social relations.

- Emotional Use: the ability to implement emotional knowledge to increase motivation, improves skills, and develops positive behaviors.

- Sympathy: the ability to realize the emotions of the others and understand their feelings.

Many EI studies were conducted; Sioberg (2001) studied the relation between EI, adaptation to life and success among 2227 employees. The results showed that EI is positively correlated with: adaptation, social skills, creativity and self-esteem. The study of Allwan (2011) aimed at investigated the relationship between EI and social skills, the sample of the study consisted of 475 students from Alhussien Bin Talal University in Jordan, the results indicated that the EI level among students were high and there was a statistical significant difference in EI in favor of females. Allawzi (2012) investigated the EI level among secondary school principals in Amman and its effect upon organizational loyalty, the sample consisted of 140 principals and 280 teachers. The results showed that EI level was mid. The purpose of Gering (2012) research was to shed light on the degree to which instructor Emotional Intelligence (EI) may moderate the student/teacher relationship. Interviews were conducted to gather qualitative data on the experience of several students at a private university in the Midwest. The findings suggest that there appears to be a positive relationship between instructor EI and a positive academic experience by the student. Alharahsheh (2013) conducted a study aimed to assess the EI level among school principals at Mafraq Educational Directorate in Jordan. The sample consisted of 223 teachers. The results showed that EI level among principals was high for all EI 
domains, except for cognitive emotion domain it was mid; the results also showed that there were no statistically significant differences in EI of the teachers attributed to their experience and gender. The study of Alamarat (2014) aimed to explore the relationship between EI and the leader efficiency. The sample of the study consisted of 102 principals from Petra Directorate of Education and Wadi Sir Directorate of Education in Jordan. The results showed that the EI level among principals was mid. The study of Machera, R. and Machera, P. (2017) investigated the extent that students in higher education are presently exposed to emotional intelligence techniques as part of their curriculum. A survey and a qualitative approach were used to gather data from the students at Botho University who are enrolled in the Bsc Hons in Accounting. The results reflected that it was imperative to introduce a module on emotional intelligence in higher education. This module assists students in modifying their negative behavior and attitudes. Therefore, if this module is implemented well the academic performance in higher education especially at Botho University may be improved.

\section{Statement of the Problem}

EI is considered to be one of the most important intelligences for the academic leaders, because they display different kinds of leadership patterns inside classroom and they face many challenges that need EI skills. Cooper and Swaf (1997) indicated that the leaders who practice EI were more successful, and had strong social intelligence compared to the leaders with less EI.

According to the researcher experience as chair of Educational Psychology Department, vice dean, dean and a member of many committees in the university, he felt that there is a problem among a faculty in dealing with students emotions; which could be due to low level of EI among faculties, so the idea of this study was emerged to investigate the degree of EI skills among Tafila Technical University (TTU) faculty members. Precisely this study aimed to answer the following questions:

Q1: What is the degree of EI practice among TTU faculty members from their perspectives?

Q2: Are their statistically significant differences $(\alpha=0.05)$ in practicing EI from faculties at TTU attributed to their gender, academic rank, and college?

\section{Study Importance}

The importance of the study could be clarified through the following:

- It Highlights the EI and its effect in providing academic environment characterized by love and cooperation.

- It Explore the degree of practicing EI among faculty.

\section{Procedural Definitions}

Emotional Intelligence (EI): the ability of the individual to realize, control and organize his and others emotions (Mayer \& Salvovey, 1995). 


\section{Study Limits}

The study is limited to the following:

- The study was conducted using a sample of faculties from TTU during the 2nd semester 2016/2017.

- $\quad$ The results of the study depend on the reliability and validity of the EI scale used to collect data.

\section{Method}

\subsection{Design}

The study adopted the descriptive design because it is a suitable method for this study purposes.

\subsection{Population}

The population of the study consisted of all faculties at T.T.U (238), during the 2nd semester 2016/2017 as Table 1 shows.

Table 1. Study Population According to the College

\begin{tabular}{lll}
\hline College & No. & Ratio \\
\hline Scientific & 158 & $66 \%$ \\
humanity & 80 & $34 \%$ \\
Total & 238 & $100 \%$ \\
\hline
\end{tabular}

6.3 Sample

$64 \%$ of the population (153 faculties) was chosen using stratified sample method, as shown in Table 2 .

\section{Table 2. The Study Sample}

\begin{tabular}{lllll}
\hline College & Rank and experience & 7 years experience and less & More than 7 years experience & Total \\
\hline $\begin{array}{l}\text { Scientific } \\
\text { Colleges }\end{array}$ & Prof and associate Prof & 20 & 49 & 69 \\
$\begin{array}{l}\text { Scientific } \\
\text { Colleges }\end{array}$ & Assistance Prof+ Lecturers & 17 & 12 & 29 \\
Humanity & Prof and associate Prof. & 10 & 19 & 29 \\
Colleges & & & & \\
Humanity & Assistance Prof+ Lecturers & 15 & 11 & 26 \\
Colleges & & 62 & 91 & 153 \\
Total & & & & \\
\hline
\end{tabular}




\subsection{Instrument}

The researcher developed the EI scale using the related literature (Amarat, 2014; Alharahsha, 2013; Rfou, 2011). The initial scale was consisted of 30 items distributed into 4 domains: emotion management (6 items), social communication ( 8 items), emotion use ( 8 items), and sympathy ( 8 items). The respondents were asked to respond to the items using Likert scale (5: always, 4: often, 3: sometimes, 2: seldom, 1: Never).

\subsection{Validity}

Validity of the scale was approved through expert judgments, 8 experts in educational management, measurement and evaluation, and general management were asked to review the scale, according to their notes the instrument was modified.

\subsection{Reliability}

Reliability was checked using internal consistency (Cronbach $\alpha$ equation). Table 3 represents the findings.

\section{Table 3. Reliability of the EI Scale}

\begin{tabular}{lll}
\hline Domain & Test-retest & Internal consistency \\
\hline Emotion Management & 0.82 & 0.80 \\
Social Communication & 0.83 & 0.81 \\
Emotion Use & 0.84 & 0.79 \\
Sympathy & 0.82 & 0.80 \\
Total & 0.83 & 0.80 \\
\hline
\end{tabular}

According to Table 3 the reliability coefficients were valid and acceptable.

\subsection{Statistical Procedure}

SPSS was used for data entry and data analysis, the following statistics were calculated: means, standard deviations and MANOVA. The following criteria were used to describe the mean for items and domains: 1-2.33 low, 234-3.67 mid and 3.68-5 high.

\section{Results}

\subsection{Results for Question 1}

To answer Q1 (what is the degree of EI practices among T.T.U faculty members from their perspectives?) Means and standard deviations were used, Table 4 represents the findings. 
Table 4. Means and Standard Deviations for EI Domains

\begin{tabular}{lllll}
\hline Domain & Mean & standard deviations & Rank & Mean description \\
\hline emotion management & 3.56 & 0.865 & 1 & mid \\
social communication & 3.51 & 0.853 & 2 & mid \\
emotion use & 3.32 & 0.702 & 3 & mid \\
sympathy & 3.24 & 0.688 & 4 & mid \\
Total & 3.40 & 0.732 & & \\
\hline
\end{tabular}

Table 4 indicated that EI and their domains were mid, social communication had the highest mean; while the use of emotions domain had the lowest mean.

The results reflect the homogeneity of the sample, because the degree of EI domains was close in their means, it also resulted from the homogeneity in the university environment; which makes faculty use emotions in a similar way.

The results are similar to the findings of Allawzi (2012), but it differs from the results of Rfou (2011) which indicated that the EI was high. The means and standard deviations were computed to the items of each domain. Table 5 represents the findings for the items of social communication domain.

Table 5. Means and Standard Deviations for the Items of Social Communication Domain

\begin{tabular}{|c|c|c|c|c|c|}
\hline Item No. & item & mean & standard deviation & rank & Mean description \\
\hline 19 & $\begin{array}{l}\text { I have the sense of students feeling } \\
\text { and needs. }\end{array}$ & 3.71 & 1.03 & 1 & high \\
\hline 20 & I think that students trust me. & 3.70 & 1.25 & 2 & high \\
\hline 21 & I participate in students' speech. & 3.56 & 1.34 & 3 & mid \\
\hline 15 & $\begin{array}{l}\text { I have the ability to help students in } \\
\text { achieving their goals. }\end{array}$ & 3.54 & 1.057 & 4 & mid \\
\hline 17 & $\begin{array}{l}\text { I always communicate easily with } \\
\text { students. }\end{array}$ & 3.53 & .896 & 5 & $\operatorname{mid}$ \\
\hline 16 & $\begin{array}{l}\text { I listen to students' problem and } \\
\text { help them to solve it. }\end{array}$ & 3.52 & 1.039 & 6 & $\operatorname{mid}$ \\
\hline 18 & $\begin{array}{l}\text { I insist to build friendship with } \\
\text { students. }\end{array}$ & 3.47 & 0.960 & 7 & mid \\
\hline 22 & $\begin{array}{l}\text { I am become angry from students } \\
\text { questions. }\end{array}$ & 3.43 & 0.971 & 8 & $\operatorname{mid}$ \\
\hline
\end{tabular}

Table 5 showed that items 19 and 20 had the highest means of (3.70) respectively, while the other items had mid means. The results could be due to the ability of faculty to understand students feeling and 
solve their problems, this result is supported also by psychological theories which state that: if you understand the emotions of the others, you will be able to make successive relations with them. Means and standard deviations for emotion management were computed. Table 6 represents the findings.

Table 6. Means and Standard Deviations for Emotion Management

\begin{tabular}{|c|c|c|c|c|c|}
\hline Item No. & item & mean & standard deviation & rank & Mean description \\
\hline 6 & $\begin{array}{l}\text { I control my emotions when I deal } \\
\text { with students. }\end{array}$ & 3.93 & 1.19 & 1 & high \\
\hline 5 & $\begin{array}{l}\text { I realize my positive } \\
\text { characteristics. }\end{array}$ & 3.52 & 1.11 & 2 & mid \\
\hline 3 & $\begin{array}{l}\text { I control my feelings when I } \\
\text { exposed to risk. }\end{array}$ & 3.47 & 1.04 & 3 & mid \\
\hline 4 & I control my negative feelings. & 3.42 & 0.984 & 4 & mid \\
\hline 2 & I own fine feelings. & 3.39 & 0.989 & 5 & $\operatorname{mid}$ \\
\hline 1 & $\begin{array}{l}\text { I can talk easily about my } \\
\text { feelings. }\end{array}$ & 3.32 & 1.20 & 6 & mid \\
\hline
\end{tabular}

As shown in Table 6 item 6 had a high mean, while the rest of the items had mid means. The result could be due to the workshops that are conducted by Faculty Development Center at TTU about the skills of teaching, classroom management, understanding students' behaviors, and communication skills. Table 7 represents the findings for sympathy domain.

Table 7. Means and Standard Deviations for Sympathy Domain

\begin{tabular}{llllll}
\hline Item No. & Item & Mean & Standard Deviations & Rank & Mean description \\
\hline 23 & I am quite when I deal with students. & 3.77 & 1.09 & 1 & high \\
24 & I have the ability to understand students & 3.52 & 0.866 & 2 & mid \\
& feeling. & & & 3 & mid \\
25 & I feel students' emotional needs. & 3.33 & 0.933 & 4 & mid \\
28 & I can understand students' signs of & 3.32 & 1.07 & & mid \\
29 & feeling. & & & 6 & mid \\
30 & I feel students feeling so I pity for them. & 3.30 & 1.007 & 7 & mid \\
27 & I share students feelings. & 3.15 & 1.086 & & mid \\
\hline
\end{tabular}


Item (23) had the highest mean, while the other items had mid mean, the result of this domain could be explained by the commitment of faculty in ethics that all teaching members must practice during their work at the university. The results for management use were represented in Table 8.

Table 8. Means and Standard Deviations for Management Use

\begin{tabular}{|c|c|c|c|c|c|}
\hline Item No. & item & mean & standard deviations & rank & Mean description \\
\hline 7 & $\begin{array}{l}\text { I perform my work with } \\
\text { concentration and activity. }\end{array}$ & 3.79 & 0.991 & 1 & high \\
\hline 9 & $\begin{array}{l}\text { I can make progress under } \\
\text { pressure. }\end{array}$ & 3.77 & 1.046 & 2 & high \\
\hline 8 & $\begin{array}{l}\text { I behave patiently when I don't } \\
\text { accomplish my work. }\end{array}$ & 3.66 & 1.095 & 3 & mid \\
\hline 12 & $\begin{array}{l}\text { I can handle obstacles in my } \\
\text { work. }\end{array}$ & 3.56 & 1.050 & 4 & mid \\
\hline 11 & I enjoy my work. & 3.42 & 1.233 & 5 & mid \\
\hline 10 & $\begin{array}{l}\text { I control fatigue feelings which } \\
\text { inhibits my work. }\end{array}$ & 3.16 & 1.127 & 6 & mid \\
\hline 13 & I am responsible for my emotions. & 2.66 & 0.960 & 7 & mid \\
\hline 14 & I can work without emotions. & 2.03 & 0.965 & 8 & low \\
\hline
\end{tabular}

As shown in Table 8, item 7 had the highest mean (3.79), then item 9, the items 8, 12,11, 10 and 13 had mid mean; the reason behind that could be due to the importance of sympathetic relations between faculty and students, faculty usually treat students as if they are their brothers, sisters or sons in addition to the social relations resulted from culture and religion. Faculty is to human being who implements emotions in transferring knowledge to the students, so they can motivate them to increase their achievement.

\subsection{Results for Question 2}

Are their statistically significant differences $(\alpha=0.05)$ in practicing EI from faculty at TTU attributed to their gender, academic rank, and college? To answer $\mathrm{Q}_{2}$, descriptive statistics and MANOVA were used; Tables 9 and 10 represent the findings.

Table 9. Means and Standard Deviations for Emotion Domains According to College and Faculty Rank

\begin{tabular}{llllll}
\hline \multirow{2}{*}{ Domain } & \multirow{2}{*}{ College } & Mean & Standard Deviation & Mean & standard deviation \\
\cline { 3 - 6 } & Scientific & 3.95 & 0.50 & 3.24 & 0.87 \\
\hline \multirow{2}{*}{ Emotion management } & & & & & \multicolumn{2}{l}{ Prof or Associate Prof. } \\
\hline
\end{tabular}




\begin{tabular}{lcccccc}
\hline & humanity & 3.16 & 0.97 & 4.03 & 0.47 \\
Social communication & Scientific & 3.56 & 0.55 & 3.08 & 0.68 \\
& humanity & 2.94 & 0.67 & 3.58 & 0.61 \\
Emotion use & Scientific & 4.01 & 0.46 & 3.29 & 0.91 \\
& humanity & 3.19 & 0.89 & 4.07 & 0.57 \\
Sympathy & Scientific & 3.66 & 0.43 & 3.16 & 0.72 \\
& humanity & 2.99 & 0.70 & 3.67 & 0.59 \\
\hline
\end{tabular}

Table 9 indicated that faculty from humanity colleges (Prof and Associate Prof) had the highest means. Table 10 represents the means and standard deviations for emotional intelligence according to the faculty rank and experience.

Table 10. Means and Standard Deviations for Emotional Intelligence According to Faculty Rank and Experience

\begin{tabular}{lllllll}
\hline & & \multicolumn{2}{l}{ Prof Assistance } & \multicolumn{2}{l}{ Prof or Associate Prof. } \\
\cline { 3 - 7 } Domain & Experience & Mean & Standard Deviation & Mean & Standard Deviation \\
\hline \multirow{2}{*}{ Emotion Management } & 7 years and more & 3.08 & 0.48 & 3.22 & 0.87 \\
& Less than 7 years & 3.21 & 0.87 & 4.07 & 0.41 \\
Social Communication & 7 years and more & 3.60 & 0.39 & 3.07 & 0.68 \\
& Less than 7 years & 3.01 & 0.72 & 3.64 & 0.57 \\
Emotion Use & 7 years and more & 4.13 & 0.38 & 3.26 & 0.90 \\
\multirow{3}{*}{ Sympathy } & Less than 7 years & 3.27 & 0.84 & 4.14 & 0.51 \\
& 7 years and more & 3.70 & 0.29 & 3.13 & 0.72 \\
& Less than 7 years & 3.08 & 0.73 & 3.71 & 0.56 \\
\hline
\end{tabular}

As Table 10 shows faculty (Prof and Associate Prof) with less than 7 years experience had the highest means in emotional intelligence domains. Table 11 represents the means and standard deviations for emotional intelligence according to college and experience.

Table 11. Means and Standard Deviations for Emotional Intelligence According to College and Experience

\begin{tabular}{llllll}
\hline & & \multicolumn{2}{l}{ Scientific } & \multicolumn{2}{l}{ Humanity } \\
\cline { 3 - 7 } Domain & Experience & Mean & Standard Deviation & Mean & Standard Deviation \\
\hline \multirow{2}{*}{ Emotion Management } & 7 years and more & 3.11 & 0.85 & 4.09 & 0.49 \\
& Less than 7 years & 4.02 & 0.46 & 3.05 & 0.88 \\
Social Communication & 7 years and more & 3.02 & 0.62 & 3.61 & 0.58 \\
\hline
\end{tabular}




\begin{tabular}{llllll}
\hline \multirow{3}{*}{ Emotion Use } & Less than 7 years & 3.58 & 0.63 & 2.88 & 0.63 \\
& 7 years and more & 3.18 & 0.87 & 4.09 & 0.53 \\
\multirow{3}{*}{ Sympathy } & Less than 7 years & 4.06 & 0.53 & 3.14 & 0.89 \\
& 7 years and more & 3.06 & 0.64 & 3.71 & 0.57 \\
& Less than 7 years & 3.69 & 0.57 & 2.93 & 0.67 \\
\hline
\end{tabular}

Table 11 indicated that humanity college faculty with more than 7 years experience had the highest means. In order to examine if the differences in means were significant MANOVA was used, Table 12 represents the findings.

Table 12. MANOVA for the Effect of Faculty Rank, College and Experience upon Emotional Intelligence

\begin{tabular}{llllll}
\hline variable & Test & Test value & F & df & Sig \\
\hline Rank & Hotelling & 0.012 & 0.442 & 4 & 0.77 \\
College & Hotelling & 0.015 & 0.53 & 4 & 0.71 \\
experience & Hotelling & 0.026 & 0.916 & 4 & 0.45 \\
Rank* college & Wilks' $\lambda$ & 0.804 & 8.67 & 4 & $* 0.000$ \\
Rank* experience & Wilks' $\lambda$ & 0.728 & 13.28 & 4 & $* 0.000$ \\
College* experience & Wilks' $\lambda$ & 0.754 & 11.55 & 4 & $* 0.000$ \\
Rank* college* experience & Wilks' $\lambda$ & 0.999 & 0.046 & 4 & 0.99 \\
\hline
\end{tabular}

$*(\alpha=0.05)$.

Table 12 showed that there are statistically significant differences $(\alpha=0.05)$ in emotional intelligence attributed to the interaction between: rank* college, rank* experience and rank* college* experience. Table 13 shows MANOVA for the effect of the bi interaction between rank and experience upon emotional intelligence domains.

Table 13. MANOVA for the Effect of Interaction between: Rank* College upon Emotional Intelligence Domains

\begin{tabular}{lllllll}
\hline Source & Dependent Variable & Sum of squares & df & Mean Squares & F & Sig \\
\hline \multirow{2}{*}{ Rank* college } & Emotion Management & 10.754 & 1 & 10.754 & 31.966 & $* 0.000$ \\
& Communication & 5.471 & 1 & 5.471 & 17.896 & $* 0.000$ \\
& Emotion Use & 11.773 & 1 & 11.773 & 31.571 & $* 0.000$ \\
& Sympathy & 6.103 & 1 & 6.103 & 20.466 & $* 0.000$ \\
\cline { 2 - 7 } Rank* experience & Emotion Management & 16.602 & 1 & 16.602 & 49.348 & $* 0.000$ \\
& Communication & 7.491 & 1 & 7.491 & 24.505 & $* 0.000$ \\
\hline
\end{tabular}




\begin{tabular}{lllllll}
\hline & Emotion Use & 17.056 & 1 & 17.056 & 45.737 & $* 0.000$ \\
College* & Sympathy & 7.661 & 1 & 7.661 & 25.694 & $* 0.000$ \\
\cline { 2 - 7 } experience & Emotion Management & 15.658 & 1 & 15.658 & 46.540 & $* 0.000$ \\
& Communication & 6.680 & 1 & 6.680 & 21.854 & $* 0.000$ \\
& Emotion Use & 12.566 & 1 & 12.566 & 33.697 & $* 0.000$ \\
& Sympathy & 8.270 & 1 & 8.270 & 27.737 & $* 0.000$ \\
\hline
\end{tabular}

Table 13 showed that there are statistically significant differences in all emotional intelligence domains attributed to: interaction of college with academic rank, interaction between academic rank and experience, and interaction between college and experience in favor of: faculty from humanity colleges whose rank are Prof and Associate Prof, Prof and Associate Prof whose experience is less than 7 years, and faculty from humanity colleges whose experience is 7 years and more. In favor of humanity colleges faculty whose ranks are Prof and Associate Prof, there are statistical significant differences in all emotional domains attributed to faculty rank, college and experience.

The result could be attributed to the nature of humanity colleges which concentrate on humanity relations and life skills which enhance the mutual trust between individuals through respectful communication and taking into consideration humanity emotions, this type of relation did not exist in the scientific colleges which concentrate on figures, equations and scientific theories. The results indicated that faculty with higher academic ranks and more experience had more emotional intelligence; this could be due to the accumulated experience which enable them to be familiar and experts in their students feelings, control their emotions, applied emotions in teaching process and realize the importance of emotions as a life skill. The results are similar to the findings of Alrabei (2007) and Alharahshah (2013).

\section{Recommendations}

According to the results of study, the researcher recommends the following: universities should hold workshops about emotional intelligence and how to implement it in teaching process, especially for faculty of scientific colleges.

\section{Conclusion}

Emotional intelligence among faculty was mid and it was affected by faculty experience, rank and the college they are teaching at.

\section{References}

Alalwan, A. (2011). Emotional Intelligence and its relationship with social skills and attachment. Jordanian Journal for Educational sciences, 2(7), 125-144. 
Alamarat, M. (2014). Social Intelligence level and its relationship with leader effiecency among school principals in Jordanian. Journal of Educational sciences, 10(2), 177-190.

Alharahshah, M. (2013). Emotional Intelligence among school principals in mafrak, Jordan. Almanara Journal, 19(3), 353-381.

Allawzi, K. (2012). Social Intelligence level and its effect upon organizational loyalty among school principals in Amman (Master thesis). Middle East University.

Alrabei, F. (2007). Emotional Intelligence and its relationship with personality traits and critical thinking among yarmouk university students (Master Thesis). Yarmouk University.

Bur-on, R. (2006). The Bur-on model of Emotional social Intelligence (ESI). Dsicothema, 18, 13-25.

Cooper, R., \& swaf, A. (1997). Emotional Intelligence in leadership and organizations. New York: Grosser Putnam.

George, J. (2000). Emotional and leadership: The role of Emotional Intelligence. Human Relations, 53(8), 1027-1055. https://doi.org/10.1177/0018726700538001

Golemon, D. (1995). Emotional Intelligence. New York: batman Books.

Gering, K. (2012). Inspiring the Wonderment: Emotional Intelligence in Higher Education (Master Thesis). Faculty of the Graduate School, Marquette University.

Johnson, G. (2008). Learning styles and emotional intelligence of the adult leaner (Unpublished doctoral Dissertation). Auburn University. U.S.A.

Levinson, M. H. (1999). Working with Emotional Intelligence. ETC. review of General semantics, 56(1), 103-104.

Machera, R., \& Machera, P. (2017). Emotional Intelligence (EI) A Therapy for Higher Education Students. Universal Journal of Educational Research, 5(3), 461-471. https://doi.org/10.13189/ujer.2017.050318

Mayer, J., \& Salovey. D. (1990). Emotional Intelligence. Imagination, cognition and personality, 9 , 185-211. https://doi.org/10.2190/DUGG-P24E-52WK-6CDG

Mayer, J., \& Salovey, D. (1997). Emotional Intelligence meets standards for a traditional Intelligence. Intelligence, 27(2), 267-298.

Rfou, M. (2011). Emotional Intelligence and its relationship with university adaptation. Journal of educational and psychological sciences, 21(2), 85-115.

Sjoberg, L. (2001). Emotional Intelligence and life adjustment a validation study. Working paper series in business administration No.8, center for economic psychology Stockholm, school of Economics, Sweden. 